\title{
Role of intraoperative neurophysiological monitoring during fluorescence-guided resection surgery
}

\author{
Aiming at seemingly complete resection of diffuse gliomas under 5-ALA \\ guidance-Is it safe?
}

\author{
Juha E. Jaaskelainen
}

Received: 25 August 2013 / Accepted: 25 August 2013 /Published online: 10 September 2013

(C) Springer-Verlag Wien 2013

Acta Neurochirurgica has promoted fluorescence-guided microneurosurgery of central nervous system (CNS) tumours with a number of articles. (a) The peroral 5-ALA (Gliolan/ BLUE 400) painting method, introduced by Stummer et al. $[19,22]$ and now standard in many departments, has been discussed in intracranial malignant gliomas [5, 12, 18-20, 24], metastases [9, 17], meningiomas [3], validity of stereotactic biopsies [25], and differential diagnosis of brain lesions [10, 13]. (b) The age-old intravenous sodium fluorescein, now permanently brought from retinal angiography to microneurosurgery (YELLOW 560) [14], has been introduced in malignant gliomas $[1,16]$ and in hemangioblastomas [15]. (c) ICG or indocyanine angiography (INFRARED 800), standard in neurovascular microsurgery, has been introduced in various CNS tumours $[4,7,11,23]$. These examples are just a prelude to the future explosion of targeted visualization of brain tumour tissues and their adjacent brain tissues, based on transcriptomes, signalomes, proteomes, glycomes, and other omes.

Many of us are ardent users of 5-ALA in diffuse grade IIIIV gliomas. But, 'Is it safe?' asked Sir Laurence Olivier in Marathon Man. Others are suspicious for at least three reasons: (a) pink glioma stain is seen in a somewhat blurred microanatomical landscape (less so with sodium fluorescein), (b) pinkish areas in the resection cavity walls may hide behind thin grayish layers, and (c) pinkish areas may be spotty and diffuse, raising the worry whether they represent glioma tissue only or infiltrated white matter [8] that is still functional, and in the worst case, eloquent white matter tracts.

J. E. Jaaskelainen $(\bowtie)$

Neurosurgery, Kuopio University Hospital, P.O. Box 1777,

Kuopio 70211, Finland

e-mail: juha.e.jaaskelainen@kuh.fi
So, what is the safety of 5-ALA-guided neuronavigated microneurosurgery of diffuse gliomas when aiming at (a) seemingly complete removal, and (b) preservation of functional connectivity of the adjacent brain tissue [6] (i.e., the optimal removal in terms of possible adjuvant therapies and survival [21])?. Pastor et al. in this issue and Della Puppa et al. in a recent 2013 Acta article [5] report on 36 and 31 gliomas, respectively, in or near eloquent areas, removed using neuronavigation, 5-ALA guidance and intraoperative monitoring (IOM) such as transcranial, cortical and subcortical stimulation mapping, as well as electrocorticography (ECoG), motor evoked potential (MEPs), sensory evoked potential (SEPs) and visual evoked potential (VEPs). Pastor et al. used general anesthesia (propofol + remifentanyl) without muscle relaxant to allow stimulation mapping, while Della Puppa et al. adopted awake surgery in six cases. Why use 5-ALA + IOM in this setting, rather than 5-ALA + 3D navigated ultrasound (US) or intraoperative $3 \mathrm{~T}$ magnetic resonance imaging (MRI) (if you can afford one)? Because IOM reflects the connectomic functions to be preserved, while US and MRI reflect the connectomic architecture. A gross total resection ( $>$ $98 \%$ ) was achieved in $67 \%$ and $74 \%$, respectively. IOM warning signs during removals, as well as neurological worsening or improvement until 3 months, were recorded. These series in their complexities are important reading for neurooncological surgeons.

Which IOM warning signs and how grave $>50 \%$ decrease? total disappearance?) - under general anesthesia without muscle relaxant-would make me interrupt the removal of that particular pinkish area? I try to rely on cortical and subcortical stimulation with electromyography (EMG) responses rather than SEPs, but the ideal setting would be IOM + awake craniotomy [2], the latter not always being applicable.

Conflicts of interest None. 


\section{References}

1. Acerbi F, Broggi M, Eoli M, Anghileri E, Cuppini L, Pollo B, Schiariti M, Visintini S, Orsi C, Franzini A, Broggi G, Ferroli P (2013) Fluorescein-guided surgery for grade IV gliomas with a dedicated filter on the surgical microscope: preliminary results in 12 cases. Acta Neurochir (Wien) 155(7):1277-1286

2. Beez T, Boge K, Wager M, Whittle I, Fontaine D, Spena G, Braun S, Szelényi A, Bello L, Duffau H, Sabel M, European Low Grade Glioma Network (2013) Tolerance of awake surgery for glioma: a prospective European Low Grade Glioma Network multicenter study. Acta Neurochir (Wien) 155(7):1301-1308

3. Coluccia D, Fandino J, Fujioka M, Cordovi S, Muroi C, Landolt H (2010) Intraoperative 5-aminolevulinic-acid-induced fluorescence in meningiomas. Acta Neurochir (Wien) 152(10):1711-1719

4. d'Avella E, Volpin F, Manara R, Scienza R, Della Puppa A (2013) Indocyanine green videoangiography (ICGV)-guided surgery of parasagittal meningiomas occluding the superior sagittal sinus (SSS). Acta Neurochir (Wien) 155(3):415-420

5. Della Puppa A, De Pellegrin S, d'Avella E, Gioffrè G, Rossetto M, Gerardi A, Lombardi G, Manara R, Munari M, Saladini M, Scienza R (2013) 5-aminolevulinic acid (5-ALA) fluorescence guided surgery of high-grade gliomas in eloquent areas assisted by functional mapping. Our experience and review of the literature. Acta Neurochir (Wien) 155(6):965-972, discussion 972

6. Duffau H, Mandonnet E (2013) The "onco-functional balance" in surgery for diffuse low-grade glioma: integrating the extent of resection with quality of life. Acta Neurochir (Wien) 155(6):951-957

7. Ferroli P, Acerbi F, Albanese E, Tringali G, Broggi M, Franzini A, Broggi G (2011) Application of intraoperative indocyanine green angiography for CNS tumors: results on the first 100 cases. Acta Neurochir Suppl 109:251-257

8. Idoate MA, Díez Valle R, Echeveste J, Tejada S (2011) Pathological characterization of the glioblastoma border as shown during surgery using 5-aminolevulinic acid-induced fluorescence. Neuropathology 31(6):575-582

9. Kamp MA, Grosser P, Felsberg J, Slotty PJ, Steiger HJ, Reifenberger G, Sabel M (2012) 5-aminolevulinic acid (5-ALA)-induced fluorescence in intracerebral metastases: a retrospective study. Acta Neurochir (Wien) 154(2):223-228, discussion 228

10. Kamp MA, Santacroce A, Zella S, Reichelt DC, Felsberg J, Steiger HJ, Cornelius JF, Sabel M (2012) Is it a glioblastoma? In dubio pro 5ALA! Acta Neurochir (Wien) 154(7):1269-1273

11. Kim EH, Cho JM, Chang JH, Kim SH, Lee KS (2011) Application of intraoperative indocyanine green videoangiography to brain tumor surgery. Acta Neurochir (Wien) 153(7):1487-1495, discussion 1494-1495

12. Muragaki Y, Iseki H, Maruyama T, Tanaka M, Shinohara C, Suzuki T, Yoshimitsu K, Ikuta S, Hayashi M, Chernov M, Hori T, Okada Y, Takakura K (2011) Information-guided surgical management of gliomas using low-field-strength intraoperative MRI. Acta Neurochir Suppl 109:67-72

13. Nestler U, Warter A, Cabre P, Manzo N (2012) A case of late-onset multiple sclerosis mimicking glioblastoma and displaying intraoperative 5-aminolevulinic acid fluorescence. Acta Neurochir (Wien) 154(5):899-901

14. Rey-Dios R, Cohen-Gadol AA (2013) Technical principles and neurosurgical applications of fluorescein fluorescence using a microscopeintegrated fluorescence module. Acta Neurochir (Wien) 155(4):701-706

15. Rey-Dios R, Cohen-Gadol AA (2013) Intraoperative fluorescence for resection of hemangioblastomas. Acta Neurochir (Wien) 155(7): 1287-1292

16. Schebesch KM, Proescholdt M, Höhne J, Hohenberger C, Hansen E, Riemenschneider MJ, Ullrich W, Doenitz C, Schlaier J, Lange M, Brawanski A (2013) Sodium fluorescein-guided resection under the YELLOW $560 \mathrm{~nm}$ surgical microscope filter in malignant brain tumor surgery — a feasibility study. Acta Neurochir (Wien) 155(4):693-699

17. Schucht P, Beck J, Vajtai I, Raabe A (2011) Paradoxical fluorescence after administration of 5-aminolevulinic acid for resection of a cerebral melanoma metastasis. Acta Neurochir (Wien) 153(7):1497-1499

18. Stockhammer F, Misch M, Horn P, Koch A, Fonyuy N, Plotkin M (2009) Association of F18-fluoro-ethyl-tyrosin uptake and 5aminolevulinic acid-induced fluorescence in gliomas. Acta Neurochir (Wien) 151(11):1377-1383

19. Stummer W, Stepp H, Möller G, Ehrhardt A, Leonhard M, Reulen HJ (1998) Technical principles for protoporphyrin-IX-fluorescence guided microsurgical resection of malignant glioma tissue. Acta Neurochir (Wien) 140(10):995-1000

20. Stummer W, Reulen HJ, Novotny A, Stepp H, Tonn JC (2003) Fluorescence-guided resections of malignant gliomas - an overview. Acta Neurochir Suppl 88:9-12

21. Stummer W, van den Bent MJ, Westphal M (2011) Cytoreductive surgery of glioblastoma as the key to successful adjuvant therapies: new arguments in an old discussion. Acta Neurochir (Wien) 153(6): $1211-1218$

22. Stummer W (2013) Fluorescein for vascular and oncological neurosurgery. Acta Neurochir (Wien) 155(8):1477-1478

23. Tamura Y, Hirota Y, Miyata S, Yamada Y, Tucker A, Kuroiwa T (2012) The use of intraoperative near-infrared indocyanine green videoangiography in the microscopic resection of hemangioblastomas. Acta Neurochir (Wien) 154(8):1407-1412, discussion 1412

24. Tejada-Solís S, Aldave-Orzaiz G, Pay-Valverde E, Marigil-Sánchez M, Idoate-Gastearena MA, Díez-Valle R (2012) Prognostic value of ventricular wall fluorescence during 5-aminolevulinic-guided surgery for glioblastoma. Acta Neurochir (Wien) 154(11):1997-2002, discussion 2002

25. von Campe G, Moschopulos M, Hefti M (2012) 5-Aminolevulinic acid-induced protoporphyrin IX fluorescence as immediate intraoperative indicator to improve the safety of malignant or highgrade brain tumor diagnosis in frameless stereotactic biopsies. Acta Neurochir (Wien) 154(4):585-588, discussion 588 